ISSN 0258-7122

Bangladesh J. Agril. Res. 39(1): 13-21, March 2014

\title{
INBRED AND HYBRID SEED PRODUCTION POTENTIALITY OF TOMATO (Lycopersicon esculentum) GENOTYPES AND THEIR YIELD PERFORMANCE DURING SUMMER
}

\author{
L. YESMIN ${ }^{1}$, M. S. ISLAM ${ }^{2}$, M. M. RAHMAN ${ }^{3}$ \\ M. N. UDDIN ${ }^{4}$ AND S. AHMAD 5
}

\begin{abstract}
An investigation was made with a view to estimating inbred and hybrid seed production potentiality as well as fruit yield potentiality of 11 tomato genotypes and their hybrids during November 2009 to September 2010 at Bangladesh Agricultural Research Institute, Gazipur. The highest number of fruits per plant was recorded from the genotype C41 (59.66). The highest fruit yield per plant $(2.94 \mathrm{~kg})$ was recorded from the genotype WP8 followed by that of C11 $(2.93$ $\mathrm{kg}$ ). In respect of seed yield performance, the genotype C51 produced the highest number of seeds per fruit (47.66), while the line C41 produced the highest seed yield per plant (7.66 g). Per hectare seed yield varied from $263.0 \mathrm{~kg}$ (C41) to $53.79 \mathrm{~kg}$ (MP5). The highest per plant (6.33 g) and per hectare (139.26 $\mathrm{kg}$ ) hybrid seeds were produced by the cross combination of C11 X C51 followed by that of WP8 $\times$ C11. The fruit weight and fruit yield of the hybrids were much higher compared to their superior parents during the summer season. Among the six tomato hybrids, WP7 X C51 had the highest fruit weight (67.60 g) and produced the highest fruit yield per plant $(1.43 \mathrm{~kg})$ followed by BARI Hybrid Tomato-4 (1.24 kg). The other two hybrids, WP8 X C51 (1.08 kg/plant) and C51 X WP10 (1.1 kg/plant) were also found promising.
\end{abstract}

Keywords: Tomato genotype, inbred, cross combination, hybrid seed.

\section{Introduction}

Tomato (Lycopersicon esculentum L.) is an important vegetable crop around the globe. This crop is mostly grown during winter in Bangladesh. Production of tomato during summer in Bangladesh is very limited. Bangladesh Agricultural Research Institute (BARI) has developed tomato hybrids which are gaining popularity among the growers. However, seed is the most important input for increasing agricultural production. Use of hybrid variety is a great option to increase yield for most of the vegetable crops (AVRDC, 1993). The use of hybrid tomato varieties has increased considerably throughout the world and have many advantages compared to open pollinated ones. Many farmers prefer to grow crops using hybrid seeds in spite of the higher seed cost. Hybrid tomato seed

\footnotetext{
${ }^{1}$ Research student, Dept. of Horticulture, Bangabandhu Sheikh Mujibur Rahman Agricultural University (BSMRAU), Gazipur, ${ }^{2}$ Associate Professor, Dept. of Horticulture, Sylhet Agricultural University (SAU) ${ }^{3}$ Professor, Dept. of Horticulture, BSMRAU, Gazipur, ${ }^{4 \& 5}$ Scientifc Officer and Chief Scientific Officer, respectively, HRC, Bangladesh Agricultural Research Institute (BARI), Gazipur, Bangladesh.
} 
production is relatively a new technology for Bangladesh. However, hybrid tomato seed production is not an easy task (Opena et al., 1993). Maintenance and seed production potentiality of the parental lines is also important in the hybrid seed production programme (Rashid and Singh, 2000). Therefore, amount of seeds produced from single plant of the inbred line or from a single cross between the inbreds are also important. Seed companies (Private) who are intended to produce $F_{1}$ seeds of tomatoes often asked about the seed production capability of the inbred lines itself and their crosses from per unit area. Precise information regarding seed production potentiality of the superior inbreds and hybrids from their crosses are scanty. Therefore, the present study was undertaken to estimate inbred and hybrid seed production potentiality of tomato genotypes and to observe the yield performance of the developed hybrids and inbreds during the summer season in Bangladesh.

\section{Materials and Method}

The experiment was conducted at the experimental field of Olericulture Division of Horticulture Research Centre (HRC), BARI, Gazipur, Bangladesh during November 2009 to September 2010. Eleven promising tomato inbred lines were collected from Olericulture Division of Horticulture Research Centre, BARI, Gazipur, for this study. These were C11, C41, C51, C71, FP5, MP5, WP2, WP6, WP7, WP8, and WP10. Seeds of 11 tomato inbred lines were sown in seed bed on 12 October 2009. Thirty days old seedlings were transplanted in the experimental field on 10 November 2009. The experiment was laid out in randomized complete block design (RCBD) with three replications. The unit plot size was $1.0 \mathrm{~m} \times 4.8 \mathrm{~m}$ having double row per bed and 12 plants per row and 24 plants per plot. Plants were spaced at $60 \mathrm{~cm} \times 40 \mathrm{~cm}$ between plant to plant and row to row, respectively. The crop was fertilized with cattle dung, urea TSP, and MP at the rate of 15 tons, $300 \mathrm{~kg}, 200 \mathrm{~kg}$, and $150 \mathrm{~kg}$ per hectare, respectively (Rashid and Singh, 2000). Half of the quantity of cattle dung and the entire amount of TSP were applied during land preparation. The remaining cattle dung and half of MP were applied before 5 days of planting. The whole of urea and half of MP were applied in 3 equal splits as top dressing at 15, 30, and 50 days after transplanting. Observations of fruit yield and yield attributes were recorded from each genotype. Collected data were subjected to MSTAT software for analysis of variance and mean separation.

Based on the field evaluation of tomato hybrids in 2007 and 2008 (Islam et al., 2011), eight superior cross combinations of tomato were considered in the present study to estimate hybrid seed yield potentiality. These were $\mathrm{C} 11 \times \mathrm{C} 51$, C41 × C71, WP2 $\times$ WP6, FP5 $\times$ MP5, WP8 $\times$ C11, WP8 $\times$ C51, WP7 $\times$ C51, and C51 $\times$ WP10. Seeds of male parents were sown in 12 October 2009 in raise seedbed, while seeds of female parents sown on 19 October 2009. Male parent was earlier than female parent to assure adequate supply of pollen for pollination 
of female parent. This experiment was conducted in RCB design with three replications. Unit bed size was $0.70 \mathrm{~m} \times 7.5 \mathrm{~m}$ having single row per bed in which seedlings were transplanted in $50 \mathrm{~cm}$ apart. So, there were 15 plants per bed. This was done for proper emasculation and pollination of flower in each bed. In crossing block, there were 24 unit beds in which cross combinations were allotted randomly. Planting of seedling of female parents were made on 19 November 2009. In this study, a ratio of 5 females to one male plant was used. Male block was made $100 \mathrm{~m}$ apart from the crossing block to avoid pollen contamination. Male parent seedlings were transplanted on 12 November 2009 in a double row bed where planting geometry was maintained at $60 \mathrm{~cm}$ and 50 $\mathrm{cm}$ between row to row and plant to plant, respectively. For hybrid seed production, emasculation, artificial pollination, and seed collection were made as per AVRDC (1993).

For summer season evaluation, six hybrid combinations and their respective eight parental lines were evaluated at the experimental field of Olericulture Division, HRC, BARI, Gazipur during the summer season of 2010. The two hybrid combinations, $\mathrm{C} 41 \times \mathrm{C} 71$ and WP2 $\times$ WP6 were not included in this study since these two combinations were already released as BARI Hybrid Tomato-3 and BARI Hybrid Tomato-5. The hybrid C11 $\times$ C51 was also released as BARI Hybrid Tomato-4, it was included in this experiment as a check variety. The seeds of the hybrids and inbred lines were sown in the seed bed on 11 May 2010. Seedlings were transplanted in the main field on 10 June 2010. The experiment was laid out in RCB design with three replications. The unit plot size was $4.80 \mathrm{~m}$ x $2.3 \mathrm{~m}$ accommodating 4 rows. Each row consisted of 12 plants. Spacing was maintained at $60 \mathrm{~cm} \times 40 \mathrm{~cm}$ between row to row and plant to plant, respectively. The crop was protected from rain providing polythene tunnel. Irrigation, pruning, mulching weeding, and other intercultural operations were done as needed. Related data for hybrids and inbred lines were recorded separately for yield and yield contributing characters and statistically analyzed using MSTAT software. However, out of eight parental lines, three of them did not flower at all (WP7, WP8, and WP10). Therefore, data generated from five parental lines are included in this experiment.

\section{Results and Discussion}

Results pertaining to yield and yield contributing traits are discussed below:

Seed yield and yield attributes of tomato inbred lines are presented in Table 1. The line C41 had maximum number of fruits (59.66) per plant, which was significantly different from all other inbred lines. The inbred line MP5 produced the minimum fruits per plant (21.66). Ahmed (1993) reported that the fruits per plant ranged from 17.80 to 179.59 . Roy (2009) mentioned the number of fruits per plant ranged from 35 to 76.39. These differences might be due to difference of cultivars used in the present study. There was a great variation in fruit weight 
(41.66 $\mathrm{g}$ to $112.66 \mathrm{~g}$ ) among the 11 tomato inbred lines. The highest fruit weight was recorded in the inbred line MP5 (112.66 g), while it was the lowest for C41 $(41.66 \mathrm{~g})$. Ahmed (1993) found that the individual fruit weight varied from 29 to $83 \mathrm{~g}$. Fruit yield per plant of different inbred lines ranged from $2.94 \mathrm{~kg}$ to 2.03 $\mathrm{kg}$. The inbred line WP8 yielded the highest amount of fruit $(2.94 \mathrm{~kg} / \mathrm{plant})$. The inbred line FP5 yielded minimum $(2.03 \mathrm{~kg} / \mathrm{plant})$, which was similar to C71, WP2 and MP5. Ahmed (1993) reported yield range of $1.47-6.50 \mathrm{~kg}$ during early planting.

The highest number of seeds per fruit was (57.66) recorded in C51, while it was lowest in FP5 (35.00). Patwary (2009) reported that number of seeds per fruit ranged from 26.0 to 107.70 during winter and 4.02 to 49.39 during summer. The maximum seed yield per plant was recorded in the inbred line C41 (7.97 g), which was statistically similar to C11 (7.66 g). The lowest seed yield per plant was $1.63 \mathrm{~g}$ as recorded in the inbred line MP5. The line MP5 produced the highest 1000-seed weight $(3.02 \mathrm{~g})$, whereas WP2 produced the lowest $(2.0 \mathrm{~g})$. Patwary (2009) reported that the range of 1000-seed weight varied from $2.29 \mathrm{~g}$ to $3.28 \mathrm{~g}$ during winter and $1.53 \mathrm{~g}$ to $3.02 \mathrm{~g}$ during summer. Among the tomato inbred lines, the line C41 produced the highest seed yield $(263.01 \mathrm{~kg} / \mathrm{ha})$ closely followed by C11 $(252.78 \mathrm{~kg} / \mathrm{ha})$ and C51 $(205.59 \mathrm{~kg} / \mathrm{ha})$.

Table 1. Seed yield and yield attributes of eleven tomato inbred lines.

\begin{tabular}{c|c|c|c|c|c|c|c}
\hline $\begin{array}{c}\text { Inbred } \\
\text { line }\end{array}$ & $\begin{array}{c}\text { No. of } \\
\text { fruits/ } \\
\text { plant }\end{array}$ & $\begin{array}{c}\text { Individual } \\
\text { fruit wt }(\mathrm{g})\end{array}$ & $\begin{array}{c}\text { Fruit } \\
\text { yield/ } \\
\text { plant } \\
(\mathrm{kg})\end{array}$ & $\begin{array}{c}\text { Seeds/ } \\
\text { fruit }\end{array}$ & $\begin{array}{c}\text { Seed } \\
\text { yield/ } \\
\text { plant } \\
(\mathrm{g})\end{array}$ & $\begin{array}{c}1000- \\
\text { seed } \\
\text { wt }(\mathrm{g})\end{array}$ & $\begin{array}{c}\text { Seed yield } \\
(\mathrm{kg} / \mathrm{ha})\end{array}$ \\
\hline C11 & $49.66 \mathrm{~b}$ & $59.00 \mathrm{~d}-\mathrm{f}$ & $2.93 \mathrm{a}$ & $54.66 \mathrm{ab}$ & $7.66 \mathrm{a}$ & $2.97 \mathrm{a}$ & $252.78 \mathrm{a}$ \\
C41 & $59.66 \mathrm{a}$ & $41.66 \mathrm{f}$ & $2.48 \mathrm{a}-\mathrm{c}$ & $47.66 \mathrm{ab}-\mathrm{c}$ & $7.97 \mathrm{a}$ & $3.0 \mathrm{a}$ & $263.01 \mathrm{a}$ \\
C51 & $38.66 \mathrm{~d}$ & $72.00 \mathrm{~cd}$ & $2.78 \mathrm{ab}$ & $57.66 \mathrm{a}$ & $6.23 \mathrm{ab}$ & $2.54 \mathrm{bc}$ & $205.59 \mathrm{ab}$ \\
C71 & $46.66 \mathrm{bc}$ & $59.00 \mathrm{~d}-\mathrm{f}$ & $2.48 \mathrm{a}-\mathrm{c}$ & $41.00 \mathrm{bc}$ & $4.54 \mathrm{bc}$ & $2.51 \mathrm{c}$ & $149.82 \mathrm{bc}$ \\
FP5 & $41.33 \mathrm{~cd}$ & $49.33 \mathrm{f}$ & $2.03 \mathrm{c}$ & $35.00 \mathrm{c}$ & $3.26 \mathrm{~cd}$ & $2.54 \mathrm{c}$ & $107.58 \mathrm{~cd}$ \\
MP5 & $21.66 \mathrm{~g}$ & $112.66 \mathrm{a}$ & $2.43 \mathrm{bc}$ & $36.33 \mathrm{c}$ & $1.63 \mathrm{~d}$ & $3.02 \mathrm{a}$ & $53.79 \mathrm{~d}$ \\
WP2 & $29.66 \mathrm{ef}$ & $79.00 \mathrm{bc}$ & $2.34 \mathrm{bc}$ & $56.66 \mathrm{ab}$ & $4.03 \mathrm{~b}-\mathrm{d}$ & $2.00 \mathrm{~d}$ & $132.99 \mathrm{bcd}$ \\
WP6 & $34.66 \mathrm{de}$ & $75.00 \mathrm{~cd}$ & $2.57 \mathrm{ab}$ & $54.66 \mathrm{ab}$ & $5.00 \mathrm{bc}$ & $2.96 \mathrm{a}$ & $165.0 \mathrm{bc}$ \\
WP7 & $37.00 \mathrm{~d}$ & $69.33 \mathrm{c}-\mathrm{e}$ & $2.56 \mathrm{ab}$ & $46.00 \mathrm{a}-\mathrm{c}$ & $4.45 \mathrm{bc}$ & $2.99 \mathrm{a}$ & $148.85 \mathrm{bc}$ \\
WP8 & $39.33 \mathrm{~d}$ & $75.00 \mathrm{~cd}$ & $2.94 \mathrm{a}$ & $50.33 \mathrm{a}-\mathrm{c}$ & $4.08 \mathrm{~b}-\mathrm{d}$ & $2.36 \mathrm{~cd}$ & $134.64 \mathrm{bcd}$ \\
WP10 & $27.66 \mathrm{fg}$ & $95.00 \mathrm{~b}$ & $2.60 \mathrm{ab}$ & $37.33 \mathrm{c}$ & $3.47 \mathrm{~cd}$ & $2.8 \mathrm{bc}$ & $114.81 \mathrm{~cd}$ \\
\hline F-test & $* *$ & $* *$ & $*$ & $*$ & $* *$ & $* *$ & $* *$ \\
CV(\%) & 7.27 & 10.05 & 9.88 & 17.42 & 20.34 & 15.5 & 20.51 \\
\hline
\end{tabular}

\section{Hybrid seed production potentiality of different cross combinations}

Seed yield and yield attributes of different hybrid combinations are presented in Table 2.0. The cross combination $\mathrm{C} 41 \times \mathrm{C} 71$ produced the highest number of 
fruits per plant (51.33), which was statistically similar to cross combination C11 $\times$ C51 (46.67). The cross combination WP $2 \times$ WP6 produced the lowest fruits per plant (26.67). Similar trend was also recorded for fruit yield per plant. The combination WP8 $\times \mathrm{C} 11$ produced the highest amount of fruits per plant $(2.90$ $\mathrm{kg}$ ), while it was the lowest for the combination of FP5 $\times$ MP5 $(1.77 \mathrm{~kg})$. Number of $\mathrm{F}_{1}$ seeds per fruit was the highest for cross combination of $\mathrm{C} 11 \times \mathrm{C} 51$ (52.67) followed by $\mathrm{C} 41 \times \mathrm{C} 71$ (46.67). The lowest $\mathrm{F}_{1}$ seeds per fruit was recorded from the cross combination $\mathrm{C} 51 \times \mathrm{WP} 10$ (41.33). $\mathrm{F}_{1}$ seed yield per plant as well per hectare greatly varied among different cross combinations. The combination $\mathrm{C} 11 \times \mathrm{C} 51$ produced the highest seed yield per plant $(6.33 \mathrm{~g})$ as well as per hectare $(139.26 \mathrm{~kg})$, which was statistically different from all other cross combinations. The cross combination WP2 $\times$ WP6 produced the lowest seed yield per plant $(2.81 \mathrm{~g})$. The cross combination WP8 $\times \mathrm{C}-11$ produced the highest 1000 -seed weight $(3.34 \mathrm{~g})$ where FP5 $\times$ MP5 produced the lowest $(2.15$ g) 1000-seed weight.

Table 2. $F_{1}$ seed yield and yield attributes of eight cross combinations of tomato.

\begin{tabular}{c|c|c|c|c|c|c}
\hline $\begin{array}{c}\text { Cross } \\
\text { combination }\end{array}$ & Fruits/plant & $\begin{array}{c}\text { Fruit yield/ } \\
\text { plant }(\mathrm{kg})\end{array}$ & $\begin{array}{c}\text { Seeds/ } \\
\text { fruit }\end{array}$ & $\begin{array}{c}\text { Seed } \\
\text { yield/ } \\
\text { plant }(\mathrm{g})\end{array}$ & $\begin{array}{c}1000- \\
\text { seed wt } \\
(\mathrm{g})\end{array}$ & $\begin{array}{c}\text { Seed yield } \\
(\mathrm{kg} / \mathrm{ha})\end{array}$ \\
\hline $\mathrm{C} 11 \times \mathrm{C} 51$ & $46.67 \mathrm{ab}$ & $2.46 \mathrm{ab}$ & $52.67 \mathrm{a}$ & $6.33 \mathrm{a}$ & $2.61 \mathrm{bc}$ & $139.26 \mathrm{a}$ \\
$\mathrm{C} 41 \times \mathrm{C} 71$ & $51.33 \mathrm{a}$ & $2.06 \mathrm{~b}$ & $46.67 \mathrm{ab}$ & $5.10 \mathrm{c}$ & $2.20 \mathrm{c}$ & $112.2 \mathrm{c}$ \\
$\mathrm{WP} 2 \times \mathrm{WP} 6$ & $26.67 \mathrm{c}$ & $2.05 \mathrm{~b}$ & $44.00 \mathrm{~b}$ & $2.81 \mathrm{e}$ & $2.41 \mathrm{c}$ & $61.82 \mathrm{e}$ \\
$\mathrm{FP5} \times \mathrm{MP5}$ & $36.67 \mathrm{bc}$ & $1.77 \mathrm{~b}$ & $42.67 \mathrm{~b}$ & $3.33 \mathrm{~d}$ & $2.15 \mathrm{c}$ & $73.26 \mathrm{~d}$ \\
$\mathrm{WP} 8 \times \mathrm{C} 11$ & $38.67 \mathrm{bc}$ & $2.90 \mathrm{a}$ & $45.67 \mathrm{~b}$ & $5.66 \mathrm{~b}$ & $3.34 \mathrm{a}$ & $124.52 \mathrm{~b}$ \\
$\mathrm{WP} 8 \times \mathrm{C} 51$ & $28.67 \mathrm{c}$ & $2.14 \mathrm{~b}$ & $42.33 \mathrm{~b}$ & $3.20 \mathrm{~d}$ & $2.66 \mathrm{bc}$ & $70.4 \mathrm{~d}$ \\
$\mathrm{WP7} \times \mathrm{C} 51$ & $33.33 \mathrm{c}$ & $2.24 \mathrm{ab}$ & $42.33 \mathrm{~b}$ & $5.10 \mathrm{c}$ & $3.10 \mathrm{ab}$ & $112.2 \mathrm{c}$ \\
$\mathrm{C} 51 \times \mathrm{WP} 10$ & $35.67 \mathrm{bc}$ & $2.49 \mathrm{ab}$ & $41.33 \mathrm{~b}$ & $3.26 \mathrm{~d}$ & $2.31 \mathrm{c}$ & $71.72 \mathrm{~d}$ \\
\hline $\mathrm{F}-\mathrm{test}$ & $* *$ & $* *$ & $*$ & $* *$ & $* *$ & $* *$ \\
$\mathrm{CV}(\%)$ & 12.92 & 12.26 & 7.89 & 3.60 & 9.79 & 3.68 \\
\hline
\end{tabular}

\section{Relationship between seed yield and other characters}

A positive and linear relationship was observed between seed yield versus number of fruits per plant, fruit yield per plant, and number of seeds per fruit (Fig. 1.1, 1.2, and 1.3). The equation for seed yield and number of fruits per plant was $y=2.5273 x+1.6301$ and the value of coefficient of determination was 0.5127 . This indicated that $51 \%$ of total variation in seed yield increase was attributed by fruits per plant. The coefficient of determination $\left(\mathrm{R}^{2}=0.2969\right)$ for seed yield and fruit yield per plant indicated that seed yield increase was not largely influenced by fruit yield per plant. Similarly $57 \%$ of total variation in seed yield increase was attributed by seeds per fruit $\left(R^{2}=0.5707\right)$. The relationship between seed yield with different characters, namely fruits per plant, 
fruit yield per plant and seeds per fruit revealed that in each case, the value of coefficient of determination was positive and much less than unity. This indicated that seed yield was not the result of any single character only rather a combination of characters contributed to increase the seed yield.

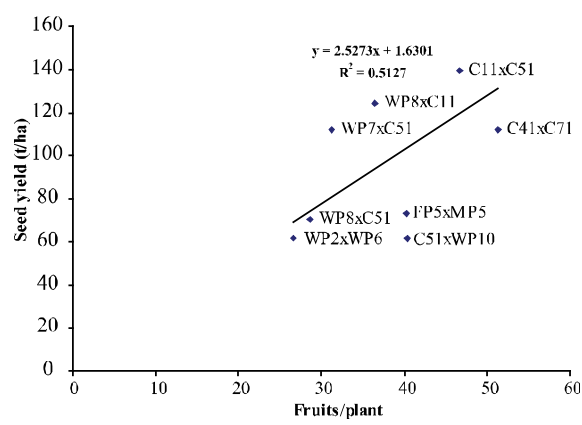

Fig. 1.1. Relationship between seed yield and number of fruits per plant.

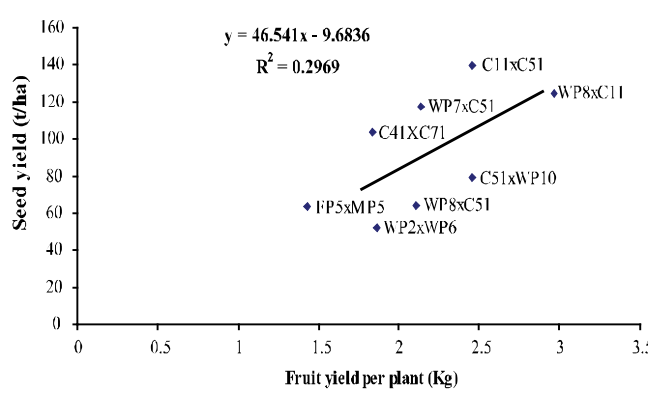

Fig.2.3. Relationship between seed yield and fruit yield per plant.

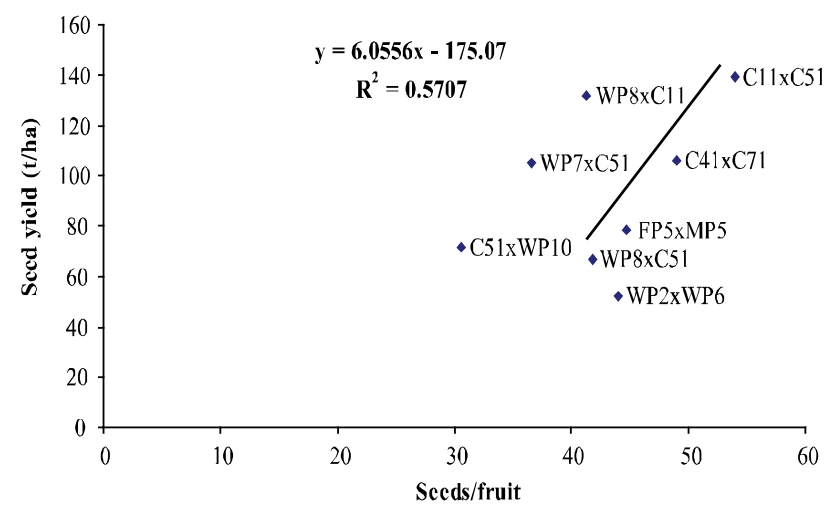

Fig. 1.3. Relationship between seed yield (t/ha) and seeds per fruit.

\section{Performance of tomato hybrids and their parental lines during summer} season

Results pertaining to yield and yield attributes of different parental lines are presented in Table 3.0. The parental lines differed significantly in all the parameters studied except days to flower, fruit breadth, and TSS (\%). The line C11 produced the highest fruits per plant (20.8), which was statistically identical with that of C41 (19.47). The lowest fruits per plant were recorded from the line FP5 (9.73). The highest fruit weight was observed in C51 (36.27g) followed by that of $\mathrm{C} 11(27.92 \mathrm{~g})$ and $\mathrm{C} 71(25.45 \mathrm{~g})$. The line C41 produced the fruit having lowest fruit weight $(19.95 \mathrm{~g})$. In winter, larger fruit was produced in all the genotypes as compared to that of summer (Table 1.0) due to low temperature. Went (1957) obtained three times larger fruit at $14^{\circ} \mathrm{C}$ night temperature compared 
to $26^{\circ} \mathrm{C}$. Fruit length of different inbred lines ranged from $3.24 \mathrm{~cm}$ to $5.48 \mathrm{~cm}$. The highest amount of fruit was harvested from the plant of the line C11 (580.9 $\mathrm{g}$ ), which was statistically identical to that of C51 (553.5 g). The lowest amount of fruit was harvested from the line FP5 (210 g).

Table 3. Yield and yield attributes of tomato parental lines during summer season.

\begin{tabular}{c|c|c|c|c|c|c|c|c}
\hline Inbred & $\begin{array}{c}\text { Days to 1 } \\
\text { flower }\end{array}$ & $\begin{array}{c}\text { Fruits/ } \\
\text { plant }\end{array}$ & $\begin{array}{c}\text { Fruit wt } \\
(\mathrm{g})\end{array}$ & $\begin{array}{c}\text { Fruit } \\
\text { length } \\
(\mathrm{cm})\end{array}$ & $\begin{array}{c}\text { Fruit } \\
\text { breadth } \\
(\mathrm{cm})\end{array}$ & $\begin{array}{c}\text { Fruit yield/ } \\
\text { plant } \\
(\mathrm{g})\end{array}$ & $\begin{array}{c}\text { TSS } \\
(\%)\end{array}$ & $\begin{array}{c}\text { Locule } \\
\text { number/fruit }\end{array}$ \\
\hline $\mathrm{C} 11$ & 46.33 & $20.8 \mathrm{a}$ & $27.92 \mathrm{~b}$ & $4.16 \mathrm{ab}$ & 3.78 & $580.9 \mathrm{a}$ & 4.6 & $2.86 \mathrm{~b}$ \\
$\mathrm{C} 41$ & 46.33 & $19.47 \mathrm{a}$ & $19.95 \mathrm{c}$ & $5.00 \mathrm{a}$ & 3.61 & $390.0 \mathrm{~b}$ & 5.86 & $2.60 \mathrm{~b}$ \\
$\mathrm{C} 51$ & 46.00 & $15.26 \mathrm{~b}$ & $36.27 \mathrm{a}$ & $3.24 \mathrm{c}$ & 4.4 & $553.5 \mathrm{a}$ & 5.12 & $5.06 \mathrm{a}$ \\
$\mathrm{C} 71$ & 48.67 & $13.3 \mathrm{~b}$ & $25.45 \mathrm{~b}$ & $5.48 \mathrm{a}$ & 3.49 & $340.0 \mathrm{~b}$ & 5.26 & $2.2 \mathrm{~b}$ \\
$\mathrm{FP5}$ & 46.33 & $9.73 \mathrm{c}$ & $21.13 \mathrm{bc}$ & $4.65 \mathrm{ab}$ & 4.05 & $210.0 \mathrm{c}$ & 4.19 & $2.2 \mathrm{~b}$ \\
\hline F-test & $\mathrm{ns}$ & $* *$ & $* *$ & $*$ & $\mathrm{~ns}$ & $* *$ & $\mathrm{~ns}$ & $* *$ \\
CV(\%) & 12.2 & 8.5 & 7.5 & 13.2 & 15.2 & 6.5 & 8.6 & 9.5 \\
\hline
\end{tabular}

Performances of six heat tolerant studied tomato hybrids are presented in Table 4.0. Most of the parameters were significantly different among the hybrids except fruit breadth and TSS. The hybrids WP7 $\times$ C51 and C51 $\times$ WP10 required the minimum days to flowering (44.33 days), while it was the highest for the hybrid WP8 $\times$ C11 (48.66). Fruit length ranged from $4.02 \mathrm{~cm}$ to $5.1 \mathrm{~cm}$ of which WP8 $\times$ C11 had the highest fruit length closely followed by FP5 $\times$ MP5 (5.04 $\mathrm{cm})$. The highest number of fruits per plant was harvested from BARI Hybrid Tomato-4 (26.00) closely followed by that of FP5 $\times$ MP5 (23.40) and the lowest for the hybrid WP8 $\times$ C11 (14.20). Similar variation in fruits per plant of 12 summer tomato hybrids was reported by Anon. (2009). Fruit weight of the hybrids ranged from $40.53 \mathrm{~g}$ to $67.60 \mathrm{~g}$. Similar variation for fruit weight was observed when 12 newly developed summer tomato hybrid was evaluated during 2009-2010 at HRC, Gazipur (Anon., 2010). Comparing fruit weight of the parental line and the hybrids, a remarkable weight improvement of fruit was achieved in all the hybrids from that of their respective parental lines. This achievement was attributed due to heterotic effect of the hybrids. Similar heterotic effect for fruit weight was also reported by Ahamed (2005). The highest yield increase over better parent was recorded from the hybrid FP5 $\times$ MP5 $(352.28 \%)$ followed by that of WP7 $\times$ C51 $(158.35 \%)$. However, the highest amount of fruit was produced by the hybrid WP7 $\times$ C51 $(1.43 \mathrm{~kg} / \mathrm{plant})$ closely followed by that of BARI Hybrid Tomato-4 (1.24 kg/plant). Therefore, the hybrid WP7 $\times$ C51 was promising and can be taken to the regional yield trial with a view to releasing as commercial hybrid for the summer season in Bangladesh. The hybrids WP8 $\times$ C51 and C51 $\times$ WP10 produced more than one $\mathrm{kg}$ of fruits per plant indicating promising for summer season. 
Table 4. Yield and yield attributes of tomato hybrids during summer.

\begin{tabular}{|c|c|c|c|c|c|c|c|c|}
\hline Hybrid & $\begin{array}{l}\text { Days to } \\
\text { flower }\end{array}$ & Fruits/ plant & $\begin{array}{l}\text { Fruit wt } \\
\text { (g) }\end{array}$ & $\begin{array}{l}\text { Fruit length } \\
\quad(\mathrm{cm})\end{array}$ & $\begin{array}{c}\text { Fruit } \\
\text { breadth } \\
(\mathrm{cm})\end{array}$ & $\begin{array}{c}\text { Fruit } \\
\text { yield/ plant } \\
(\mathrm{kg})\end{array}$ & $\begin{array}{l}\text { TSS } \\
(\%)\end{array}$ & $\begin{array}{l}\text { Yield increase } \\
\text { over better } \\
\text { parent } \\
(\%)\end{array}$ \\
\hline FP5 $\times$ MP5 & $46.33 \mathrm{ab}$ & $23.40 \mathrm{ab}$ & $40.53 c$ & $5.04 \mathrm{ab}$ & 4.86 & $0.95 b c$ & 4.73 & 352.38 \\
\hline $\mathrm{WP} 8 \times \mathrm{C} 11$ & $48.66 \mathrm{a}$ & $14.20 \mathrm{c}$ & $57.97 \mathrm{ab}$ & $5.1 \mathrm{a}$ & 4.43 & $0.82 \mathrm{c}$ & 4.58 & 41.16 \\
\hline $\mathrm{WP} 8 \times \mathrm{C} 51$ & $45.33 b$ & $17.80 \mathrm{bc}$ & 61.39ab & $4.38 \mathrm{abc}$ & 4.84 & $1.08 \mathrm{bc}$ & 4.36 & 95.12 \\
\hline WP7 $\times$ C5 1 & $44.33 b$ & $21.20 \mathrm{abc}$ & $67.60 \mathrm{a}$ & $4.25 \mathrm{bc}$ & 4.85 & $1.43 \mathrm{a}$ & 4.70 & 158.35 \\
\hline $\mathrm{C} 51 \times \mathrm{WP} 10$ & $44.33 b$ & $21.33 \mathrm{abc}$ & $51.65 \mathrm{bc}$ & 4.33abc & 4.86 & $1.1 \mathrm{bc}$ & 4.46 & 98.73 \\
\hline $\begin{array}{c}\text { BARI Hybrid } \\
\text { Tomato-4 }(\mathrm{C} 11 \times \mathrm{C} 51)\end{array}$ & $45.33 b$ & $26.00 \mathrm{a}$ & $46.9 \mathrm{bc}$ & $4.02 \mathrm{c}$ & 4.32 & $1.24 \mathrm{ab}$ & 4.5 & 113.46 \\
\hline F-test & $*$ & $* *$ & $* *$ & $* *$ & $\mathrm{~ns}$ & $*$ & $\mathrm{~ns}$ & \\
\hline $\mathrm{CV}(\%)$ & 3.26 & 13.65 & 1.92 & 6.57 & 7.22 & 12.57 & 4.46 & \\
\hline
\end{tabular}




\section{Acknowledgement}

We cordially express our gratitude to National Agricultural Technology Project, Phase-1 of Bangladesh Agricultural Research Council for financial support and encouragement during the course of this research work.

\section{References}

Ahmed, S. 1993. Comparative performance of tomatoes during summer and winter. M. S. thesis, Dept. of Horticulture, IPSA, Gazipur, Bangladesh, Pp. 25-45.

Ahamed, T. 2005. Combining ability and heterosis in tomato (Lycopersicon lycopersicum L.). MS Thesis, Bangabandhu Sheikh Mujibur Rahman Agricultural University, Salna, Gazipur, Pp. 25-66.

Anonymous. 2009. Annual Research Report 2008-2009. Olericulture Division, HRC, BARI, Gazipur. P. 110.

Anonymous. 2010. Annual Research Report 2009-2010. Olericulture Division, HRC, BARI, Gazipur. Pp. 110-182.

AVRDC. 1993. Breeding of solanaceous and cole crops. Asian Vegetable Research and Development Centre, Shanhua, Tainan, Taiwan. Publication no. 92-384. P.308

Islam, M. S., S. Ahmed and M. N. Uddin. 2011. Annual Rsearch Report 2010-2011. Olericulture Division, HRC, BARI, Gazipur, Bangadesh. P.120

Opena, R. T and J. T. Chen. 1993. Production of $F_{1}$ hybrid tomato seeds. In.: Breeding of solanaceous and cole crops. A compilation of lecture materials of training course held in BARI, Gazipur. Pp. 56-67.

Patwary, M.M.A. 2009. Reproductive physiology and heterosis in heat tolerant tomato. Ph.D. Thesis. Bangabandhu Sheikh Mujibur Rahman Agricultural University, Salna, Gazipur. Pp. 1-190.

Rashid, M. A. and D. P. Singh. 2000. A manual on Vegetable Seed Production in Bangladesh. AVRDC-USAID-Bangladesh Project. HRC. Pp. 21-86.

Roy, S. K. 2009. Comparative yield and storage quality of commercial tomato varieties of Bangladesh. MS Thesis. Bangabandhu Sheikh Mujibur Rahman Agricultural University, Salna, Gazipur. Pp. 19-29.

Went, F. W. 1957. The experimental control of plant growth. Chronica Botanica Co., Waltham, Mass. Pp. 99-114. 